\title{
Monoclonal Antibodies in Cancer Therapy
}

\author{
David Zahavi ${ }^{1}$ (ID) and Louis Weiner ${ }^{2, *(1)}$ \\ 1 Tumor Biology Training Program, Lombardi Comprehensive Cancer Center, Georgetown University, \\ Medical Center, 3800 Reservoir Rd NW, Washington, DC 20007, USA; djz8@georgetown.edu \\ 2 Department of Oncology, Lombardi Comprehensive Cancer Center, Georgetown University, Medical Center, \\ 3800 Reservoir Rd NW, Washington, DC 20007, USA \\ * Correspondence: weinerl@georgetown.edu; Tel.: +1-202-687-2110
}

Received: 22 May 2020; Accepted: 4 July 2020; Published: 20 July 2020

check for updates

\begin{abstract}
Monoclonal antibody-based immunotherapy is now considered to be a main component of cancer therapy, alongside surgery, radiation, and chemotherapy. Monoclonal antibodies possess a diverse set of clinically relevant mechanisms of action. In addition, antibodies can directly target tumor cells while simultaneously promoting the induction of long-lasting anti-tumor immune responses. The multifaceted properties of antibodies as a therapeutic platform have led to the development of new cancer treatment strategies that will have major impacts on cancer care. This review focuses on the known mechanisms of action, current clinical applications for the treatment of cancer, and mechanisms of resistance of monoclonal antibody therapy. We further discuss how monoclonal antibody-based strategies have moved towards enhancing anti-tumor immune responses by targeting immune cells instead of tumor antigens as well as some of the current combination therapies.
\end{abstract}

Keywords: monoclonal antibody; cancer; immunology; antibody-dependent cellular cytotoxicity (ADCC); immune checkpoint blockade (ICB)

\section{Introduction}

Antibodies were first described as a neutralizing substance found in blood by Behring and Shibasaburo in 1890 in their work on animal models of diphtheria [1]. Over the next century several important scientific advances would pave the way for the use of antibodies as a cancer therapeutic. Antibodies were identified as proteins that could recognize specific antigens by Heidelberger and Avery, and in 1947 Astrid Fagraeus demonstrated that antibodies were produced by plasma B cells of the adaptive immune system [2,3]. Sir Gustav Nossal then proved the clonal selection theory that a single B cell clone produces one specific antibody [4]. Thus, monoclonal antibodies (mAbs) are antibodies made by clones of a unique B cell, all of which bind to specific portions of an antigen also known as an epitope. Methods to produce monoclonal antibodies involving human-mouse hybrid cells were first identified by Schwaber in 1973 and were used by Köhler and Milstein to generate the human-derived hybridomas that have since been a mainstay in the large scale production of therapeutic antibodies $[5,6]$. Soon after the discovery of hybridomas, research into the use of mAbs to treat cancer began. Anti-melanoma mAbs were shown to suppress the growth of human melanomas in nude mice and in 1980 the first human trial of mAb therapy against cancer was conducted in a lymphoma patient $[7,8]$. Unfortunately, due to the murine origins of early therapeutic monoclonal antibodies, these mAbs were immunogenic in humans and were poor inducers of immunity in patients, thereby limiting their clinical applicability. In the late 1980s, techniques emerged to humanize antibodies in order to eliminate these limitations [9]. Further advances have led to the derivation of "fully-human" antibodies using transgenic mice or in vitro yeast or phage display systems [10,11]. As a result of these antibody engineering innovations, $\mathrm{mAbs}$ have become an important modality in the treatment of cancer. 
Antibodies are unique in their ability to both directly kill tumor cells while simultaneously engage the host immune system to develop long-lasting effector responses against the tumor. The combination of a multifaceted mechanism of action with target specificity distinguishes mAb therapy from treatments such as chemotherapy and underlies the capability of antibodies to elicit strong anti-tumor responses while minimizing toxicity and adverse events. To better understand how monoclonal antibodies function as a cancer therapy, we review their structure, mechanisms of action, clinical uses, mechanisms of resistance, and some combination strategies.

\section{Antibody Structure and Function}

Antibodies are large glycoproteins that belong to the immunoglobulin (Ig) superfamily and their role in the immune system is to recognize foreign antigens, neutralize them, and elicit a further immune response. Their basic structure is composed of two heavy and two light chains in the shape of a Y. At each tip of the $Y$ lies the fragment antigen-binding (Fab) portion of the antibody which is responsible for recognition of the specific antigen. The fragment crystallizable (Fc) region located at the base of the Y structure mediates interactions between the antibody and other members of the immune system [12]. Antibody Fc regions are recognized by Fc receptors (FcRs) found on a wide range of immune cells. Based on the type of heavy chain, antibodies can be separated into five distinct classes: $\operatorname{IgA}, \operatorname{IgD}, \operatorname{IgE}$, IgG, and IgM. IgG is the most often form used in antibody therapy due to the fact that IgGs interact with their associated type of FcR, Fc $\gamma$ R, found on natural killer (NK) cells as well as neutrophils, monocytes, dendritic cells, and eosinophils to mediate specialized functions such as antibody-dependent cellular cytotoxicity (ADCC) and complement-dependent cytotoxicity (CDC). The IgG class can further be subdivided based on the ability of the Fc region to facilitate those functions: IgG1 and IgG3 are able to elicit ADCC and CDC, while IgG2 and IgG4 cannot [13]. Monoclonal antibodies represent a clonal version of a specified antibody isotype that is targeted to a unique antigen epitope.

\section{Effector Mechanisms of Targeted mAbs}

Targeted mAbs against antigens either unique to or overexpressed by tumor cells can cause tumor cell death by a variety mechanisms (Figure 1). The main direct mechanism by which many antibodies induce tumor cell death is the blockade of growth factor receptor signaling. Pro-tumor growth and survival signaling is perturbed when mAbs bind their target growth factor receptors and manipulate their activation state or block ligand binding. For example, epidermal growth factor receptor (EGFR) is overexpressed by many different cancers and signaling via EGFR leads to tumor cell proliferation, migration, and invasion. Cetuximab, which is an anti-EGFR mAb, induces apoptosis in tumor cells by blocking ligand binding and receptor dimerization [14,15]. Human epidermal growth factor receptor 2 (HER2) is a tyrosine kinase receptor that is overexpressed in many cancers but primarily ovarian and breast carcinomas [16]. It is distinct from EGFR in that it has no known ligand and instead hetero-dimerizes with other growth factor receptors to enhance their activation [17]. Antibodies targeting HER2 therefore achieve signaling perturbation by inhibiting hetero-dimerization and internalization. Trastuzumab was the first FDA approved anti-HER2 $\mathrm{mAb}$ and remains a vital component of treatments for HER2-amplified breast cancer. Indirect mechanisms of action of $\mathrm{mAbs}$ require the engagement of components of the host immune system and are CDC, antibody-dependent cellular phagocytosis (ADCP), and ADCC. Most targeted mAbs are able to activate the complement system. For instance, rituximab depends in part on CDC for its in vivo efficacy. In a preclinical model, rituximab anti-tumor effects were completely abolished by knockout of the complement cascade component C1q [18]. The importance of CDC in mAb therapy is further supported by the fact that genetic polymorphisms in the $\mathrm{C} 1 \mathrm{qA}$ gene correlate with clinical response to rituximab in patients with follicular lymphoma [19]. Likewise, optimization of CDC via antibody engineering can enhance anti-tumor activity. For example, the anti-CD20 mAb ofatumumab, which mediates amplified CDC, demonstrated greater efficacy than rituximab in a clinical trial of chronic lymphocytic leukemia (CLL) patients [20]. ADCP occurs when Fc $\gamma$ RI expressed on cells such as macrophages binds to IgG1 or IgG3 
mAbs that have opsonized a tumor cell. There have been very limited studies of ADCP; however, there is some evidence that ADCP plays an important role in destruction of circulating tumor cells following mAb therapy [21]. First described in 1965 by Erna Möeller, ADCC has since been established as an immune mechanism where target cells become opsonized by antibodies which then recruits effector cells to induce target cell death by non-phagocytic mechanisms [22]. Antibodies act as bridges between by binding to antigens on the target cell surface via their Fab portions and linking the effector cells via their Fc portions. While IgG, IgA, and IgE can all mediate ADCC, IgG1 is the most relevant subclass for anti-cancer therapeutic antibodies [23]. Effector cells must express FcR that will bind the antibody in order to facilitate ADCC [24]. Each class of antibody has a corresponding class of FCR such as $\mathrm{F}_{c} \gamma \mathrm{R}$, which binds IgG, and $\mathrm{F}_{\mathrm{c}} \alpha \mathrm{R}$, which binds IgA. Fc $\gamma \mathrm{R}$ is the most relevant class to ADCC of tumor cells and encompasses both the activating Fc $\gamma$ RI (CD64), Fc $\gamma$ RIIA (CD32A), Fc $\gamma$ RIIIA (CD16A), and inhibitory Fc $\gamma$ RIIB (CD32B) receptors [25]. When an activating Fc $\gamma$ R on an effector cell binds the Fc region of an antibody receptor crosslinking and downstream signal propagation occurs. NK cells are the main effector type that mediate ADCC; however other myeloid types such as monocytes, macrophages, neutrophils, eosinophils, and dendritic cells are also capable [26]. Effector cells induce target cell death via cytotoxic granule release, Fas signaling, and initiation of reactive oxygen species [27-29]. While several myeloid cell types have been demonstrated to mediate ADCC during immunotherapy, the clinical efficacy of most targeted mAbs is mainly NK cell dependent [30].

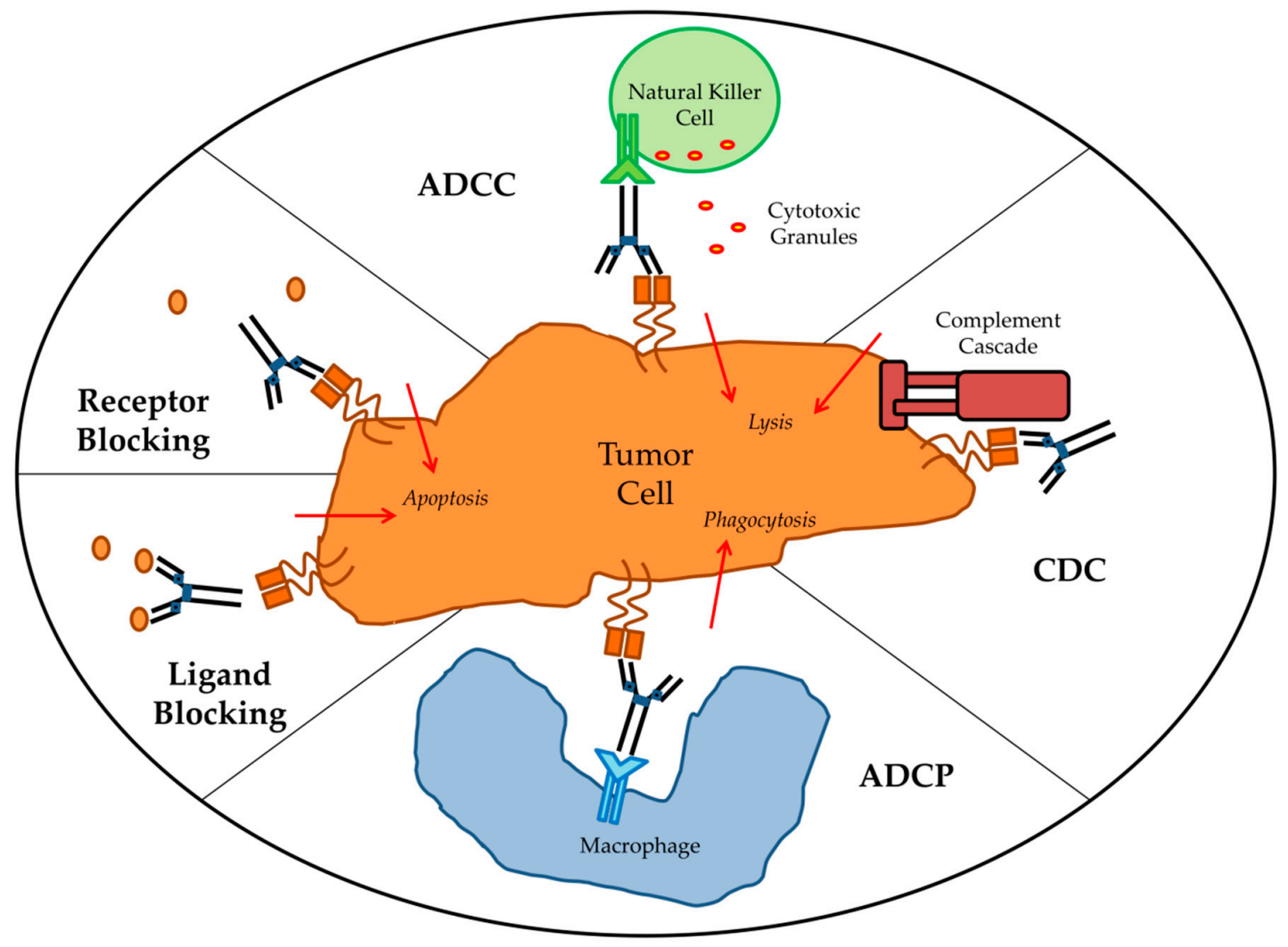

Figure 1. Antibody effector mechanisms. ADCC: antibody-dependent cellular cytotoxicity; CDC: complement-dependent cytotoxicity; ADCP: antibody-dependent cellular phagocytosis.

While many mAbs facilitate several of the above mechanisms there has been debate about which mechanisms are important in vivo. Many of the first mAb therapies were known to mediate ADCC of tumor cells in vitro, but whether ADCC was significant to their therapeutic efficacy was originally poorly understood. Using mouse models, Clynes et al. were the first to demonstrate that ADCC was an essential contributor to the in vivo activity of trastuzumab and rituximab [31]. 
Additional mechanistic studies utilizing similar mouse models confirmed that Fc $\gamma \mathrm{R}$ expression by immune effector cells is required for tumors to respond to mAb therapy [32]. Furthermore, in a novel mouse model whose immune cells had mutant Fc $\gamma$ R incapable of ADCC, mAb therapy failed to clear tumors [33]. In most of these studies the mAbs used could also act through additional mechanisms of action such as signaling perturbation. Therefore, while these results indicated ADCC was required for successful mAb therapy they did not prove whether ADCC alone was sufficient. More recent work involving $\mathrm{mAb}$ that rely exclusively on ADCC have verified that ADCC alone can mediate therapeutic benefit [34]. In humans, clinical trials have demonstrated that many mAbs eliminate tumor cells, in part, by causing ADCC. Because functioning Fc $\gamma$ Rs were critical for mAb efficacy in mouse models, clinical trial data was used to examine whether $F_{c} \gamma R$ polymorphisms would correlate with clinical outcomes. In humans, bothFc $\gamma$ RIIA and Fc $\gamma$ RIIIA are polymorphic, with certain genotypes coding for Fc $\gamma$ Rs with higher affinity for IgG1 and therefore stronger ADCC activity $[35,36]$. Lymphoma patients who had the polymorphism associated with augmented ADCC were demonstrated to have better clinical responses to rituximab in several studies [37-39]. Furthermore, both genotypes of Fc $\gamma$ RIIA and $F_{C} \gamma$ RIIIA associated with higher affinity for $F_{C}$ were robust predictors for better survival in colorectal cancer patients treated with cetuximab and metastatic breast cancer patients treated with trastuzumab respectively [40,41]. In recent studies, $\mathrm{F}_{\mathrm{C}} \gamma \mathrm{R}$ polymorphisms in breast cancer patients treated with trastuzumab or neuroblastoma patients treated with anti-GD2 mAbs were directly linked to ADCC amplitude by in vitro studies using patient derived immune cells [42,43]. These multiple analyses confirm that patients with high affinity $\mathrm{F}_{\mathrm{C}} \gamma \mathrm{R}$ that mediate stronger ADCC have better clinical outcomes when administered $\mathrm{mAb}$ therapy, irrespective of cancer type or target antigen. In addition to examining Fc $\gamma$ R polymorphisms, studies have used patient samples from clinical trials to investigate the relative importance of ADCC to therapeutic success. In one study, patients with HER2-positive breast cancer that were treated with trastuzumab had IHC staining for granzyme B performed on their tumor samples as a surrogate marker of ADCC activity. Patients who received trastuzumab were found to have better overall survival and higher levels of ADCC compared to the other cohorts [44]. Furthermore, patient-derived in vitro models demonstrated ADCC as a major therapeutic mechanism of rituximab in non-Hodgkin lymphoma and anti-CD38 antibodies in multiple myeloma [45,46]. Taken together, there is strong evidence that ADCC plays a critical role in facilitating mAb-based anti-tumor therapeutic responses in patients. In fact, additional variables that would affect ADCC activity such as target antigen expression level and density, mAb isotype, and mAb dose all correlate with clinical response [47]. The ability of $\mathrm{mAbs}$ to mediate ADCC is recognized as a major determining factor for $\mathrm{mAb}$ therapy success, and research and development of novel mAbs has shifted towards designing mAbs with improved capacity to mediate ADCC. ADCC functionality of antibodies can be enhanced by altering the $F_{c}$ portion of the $\mathrm{mAb}$ to increase their binding affinity to the activating Fc $\gamma$ RIIIA via site-directed mutagenesis, changing Fc domain glycosylation, and/or removing Fc domain fucosylation [48-51]. Next generation mAbs that are afucosylated have shown promise in clinical trials [52].

\section{Clinical Uses}

Over the past thirty years, various forms of mAb-derived treatments have been used clinically in an effort to capitalize on the potential of targeted therapy. Antibodies are extremely versatile as platforms for the development of novel therapeutics which has resulted in a large diversity of approaches. The discovery of targetable tumor-specific antigens fueled interest in designing immunotherapies [53]. Upon the emergence of mAbs, it was thought that using mAbs to target tumor cell antigens might be a more effective and less toxic treatment than traditional chemotherapy. In 1988, scientists identified a protein, CD20, which was specific to mature B cells. CD20 was found to be abundantly expressed on cancerous B cells in non-Hodgkin's lymphoma, but not found on healthy immature B cells. Therefore, a mAb treatment that targeted CD20 could eliminate the cancerous cells, but immature B cells would remain to replenish the supply of healthy cells. Thus, CD20 became the first target for 
$\mathrm{mAb}$ therapy and the anti-CD20 mAb rituximab was the first $\mathrm{mAb}$ to be approved for the treatment of cancer [54]. By targeting antigens identified as overexpressed on solid tumor cells, more mAbs have since demonstrated efficacy as cancer therapeutics. Today, mAbs directed to such targets as epidermal growth EGFR and HER2 see wide use in the clinic for the treatment of colorectal and breast cancers respectively [55,56]. In addition, there is currently a multitude of other ways that mAbs are employed in cancer therapy including antibody-drug conjugates, targeting pro-tumorigenic compounds in the microenvironment, bispecific T cell engagers (BiTEs), and immune checkpoint inhibitors. A comprehensive list of FDA approved mAb-based cancer therapies is provided in Table 1.

Table 1. FDA-approved monoclonal antibodies for cancer.

\begin{tabular}{|c|c|c|c|}
\hline Name & Antigen & Format & Indications (Year of First Approval) ${ }^{1}$ \\
\hline \multicolumn{4}{|c|}{ Unconjugated Antibodies } \\
\hline Atezolizumab & PD-L1 & Humanized IgG1 & $\begin{array}{c}\text { Bladder, Non-small cell lung (2016), } \\
\text { and Triple-negative breast (2019) } \\
\text { cancers (2019) }\end{array}$ \\
\hline Avelumab & PD-L1 & Human IgG1 & $\begin{array}{l}\text { Urothelial Carcinoma (2017) and Merkel } \\
\text { Cell Carcinoma (2017) }\end{array}$ \\
\hline Bevacizumab & VEGF & Humanized IgG1 & $\begin{array}{l}\text { Colorectal (2004), Non-small cell lung } \\
\text { (2006), Renal (2009), Glioblastoma } \\
\text { (2009), and Ovarian (2018) Cancers }\end{array}$ \\
\hline Cemiplimab & PD-1 & Human IgG4 & $\begin{array}{l}\text { Cutaneous squamous-cell } \\
\text { carcinoma (2018) }\end{array}$ \\
\hline Cetuximab & EGFR & Chimeric IgG1 & $\begin{array}{l}\text { Colorectal cancer (2004) and Head and } \\
\text { neck squamous cell carcinoma (2006) }\end{array}$ \\
\hline Daratumumab & CD38 & Human IgG1 & Multiple Myeloma (2015) \\
\hline Dinutuximab & GD2 & Chimeric IgG1 & Neuroblastoma (2015) \\
\hline Durvalumab & PD-L1 & Human IgG1 & Bladder Cancer (2017) \\
\hline Elotuzumab & SLAMF7 & Humanized IgG1 & Multiple Myeloma (2015) \\
\hline Ipilimumab & CTLA-4 & Human IgG1 & $\begin{array}{c}\text { Melanoma (2011) and Renal cell } \\
\text { carcinoma (2018) }\end{array}$ \\
\hline Isatuximab & CD38 & Chimeric IgG1 & Multiple Myeloma (2020) \\
\hline Mogamulizumab & CCR4 & Humanized IgG1 & Cutaneous T-cell lymphoma (2018) \\
\hline Necitumumab & EGFR & Human IgG1 & Non-small cell lung cancer (2015) \\
\hline Nivolumab & PD-1 & Human IgG4 & $\begin{array}{l}\text { Melanoma (2014), Lung (2015), } \\
\text { and Renal (2018) cancers }\end{array}$ \\
\hline Obinutuzumab & CD20 & Humanized IgG2 & Chronic lymphocytic leukemia (2013) \\
\hline Ofatumumab & CD20 & Human IgG1 & Chronic lymphocytic leukemia (2014) \\
\hline Olaratumab & PDGFR $\alpha$ & Human IgG1 & Sarcoma (2016) \\
\hline Panitumumab & EGFR & Human IgG2 & Colorectal Cancer (2006) \\
\hline Pembrolizumab & PD-1 & Humanized IgG4 & Melanoma (2014), Various (2015-) \\
\hline Pertuzumab & HER2 & Humanized IgG1 & Breast cancer (2012) \\
\hline Ramucirumab & VEGFR2 & Human IgG1 & Gastric cancer (2014) \\
\hline Rituximab & CD20 & Chimeric IgG1 & B-Cell Lymphoma (1997) \\
\hline Trastuzumab & HER2 & Humanized IgG1 & Breast cancer (1998) \\
\hline
\end{tabular}


Table 1. Cont.

\begin{tabular}{|c|c|c|c|}
\hline Name & Antigen & Format & Indications (Year of First Approval) ${ }^{1}$ \\
\hline \multicolumn{4}{|c|}{ Antibody-Drug Conjugates (ADCs) } \\
\hline $\begin{array}{l}\text { Gemtuzumab } \\
\text { ozogamicin }\end{array}$ & CD33 & Humanized ADC & Acute myeloid leukemia (2000) \\
\hline Brentuximab vedotin & CD30 & Chimeric ADC & $\begin{array}{l}\text { Hodgkin's lymphoma and Anaplastic } \\
\text { large-cell lymphoma (2011) }\end{array}$ \\
\hline $\begin{array}{l}\text { Trastuzumab } \\
\text { emtansine }\end{array}$ & HER2 & Humanized ADC & Breast cancer (2013) \\
\hline $\begin{array}{l}\text { Inotuzumab } \\
\text { ozogamicin }\end{array}$ & CD22 & Humanized ADC & Acute lymphoblastic leukemia (2017) \\
\hline Polatuzumab vedotin & CD79B & Humanized ADC & B-Cell Lymphoma (2019) \\
\hline Enfortumab vedotin & Nectin-4 & Human ADC & Bladder cancer (2019) \\
\hline $\begin{array}{l}\text { Trastuzumab } \\
\text { deruxtecan }\end{array}$ & HER2 & Humanized ADC & Breast cancer (2019) \\
\hline $\begin{array}{l}\text { Sacituzumab } \\
\text { govitecan }\end{array}$ & TROP2 & Humanized ADC & Triple negative breast cancer (2020) \\
\hline $\begin{array}{l}\text { Moxetumomab } \\
\text { pasudotox }\end{array}$ & CD22 & Mouse ADC & Hairy-cell leukemia (2018) \\
\hline $\begin{array}{l}\text { Ibritumomab } \\
\text { tiuxetan }\end{array}$ & CD20 & $\begin{array}{l}\text { Mouse IgG1-Y90 or } \\
\text { In111 }\end{array}$ & Non-Hodgkin's lymphoma (2002) \\
\hline $\begin{array}{l}\text { Iodine (I131) } \\
\text { tositumomab }\end{array}$ & CD20 & Mouse IgG2-I131 & Non-Hodgkin's lymphoma (2003) \\
\hline Blinatumomab & CD19, CD3 & Mouse BiTE & Acute lymphoblastic leukemia (2014) \\
\hline
\end{tabular}

Early efforts in the development of mAb therapies focused on enhancing the direct cytotoxic effects on targeted tumor cells. With the exception of the aforementioned mAbs directed against CD20, HER2, and EGFR, most mAbs have little anti-tumor activity on their own. In spite of this, the specificity of $\mathrm{mAbs}$ for tumor antigen makes them useful for delivering cytotoxic compounds directly to tumor cells. Clinically beneficial anti-tumor activity has been accomplished by conjugating mAbs with different effector molecules that cause tumor cell death after antibody binding and internalization. Effector molecules may include cytotoxic drugs, immunotoxins, and radionuclide agents. The most important consideration in antibody-conjugate design is the selection of the target, which is the main determinant of anti-tumor activity and selectivity [58]. In addition, targets must be capable of internalization upon antibody binding in order to release the drug. Brentuximab vedotin became the first antibody-drug conjugate (ADC) to be FDA approved in 2011 [59]. Brentuximab vedotin is a mAb targeting CD30 expressed by lymphoma cells linked to the microtubule destabilizing agent monomethyl auristatin E. Ado-trastuzumab emtansine is an ADC composed of trastuzumab and the cytotoxic maytansine derivative DM1 that was approved in 2013 for patients with metastatic breast cancer that is HER2-positive [60]. Eight ADCs have been approved for use in the treatment of various cancers (Table 1). ADCs targeting mesothelin, DLL3, and GPNMB, among others remain in advanced stages of clinical testing [61]. Research into ADCs continues because of improved understanding of the mechanistic basis of ADC activity that enables rational design of combinations with other cytotoxic payloads and findings indicate that ADCs may also stimulate additional anti-tumor immunity by $\mathrm{T}$ cells [62]. The second class of agents that can be delivered to tumor cells via conjugation to mAbs are biologic toxins. This method has proven difficult due to the extreme potency of the toxins, causing unacceptable toxicity in patients. Pseudomonas exotoxin A (PE) and ricin toxins are the most common toxins in targeted cancer therapy and remain under clinical investigation [63]. To date, 
only moxetumomab pasudotox, a CD22 targeted mAb linked to PE for hairy-cell leukemia, has received FDA approval [64]. The last category of antibody-based compound delivery involves radionuclides. Radioimmunotherapy uses a mAb labeled with a radionuclide as a form of targeted radiation therapy. Currently, only two radioimmunotherapies have been FDA approved: yttrium-90 (90Y)-ibritumomab tiuxetan and iodine-131 (131I)-tositumomab. Both agents utilize a mAb specific for CD20 to deliver either yttrium-90 or iodine-131 to lymphoma cells. Unfortunately, radioimmunotherapies can cause life-threatening systemic toxicity and solid tumors are often inaccessible or insensitive. Since the practicalities of preparing and delivering these agents have proved complex they have not seen widespread use, and tositumomab was discontinued by their parent company [65].

The tumor microenvironment contains many factors that are known to inhibit anti-tumor immune responses, promote tumor cell growth, and induce pro-tumorigenic angiogenesis. Targeting these critical pro-tumorigenic processes within the tumor microenvironment has proved clinically efficacious. Historically, the most relevant target has been vascular endothelial growth factor (VEGF), which is abundant in the microenvironment of many solid tumors and binds to its receptor (VEGFR) found on the tumor adjacent vascular endothelium to stimulate angiogenesis. The mAb bevacizumab, which is targets VEGF and blocks VEGF from binding to its receptor, is approved for the treatment of many different cancers [66]. Similar efforts to target VEGFRs using ramucirumab, a mAb to VEGFR2, and icrucumab, a mAb to VEGFR1, have shown promise [67,68]. Other pathways and factors that are proangiogenic such as platelet-derived growth factor (PDGF)/PDGF-receptor (PDGFR) signaling are important therapeutic targets [69]. In addition to proangiogenic targets, transforming growth factor-beta (TGF- $\beta$ ), which is secreted by some tumor cells, inhibits immune effector cell function in the tumor microenvironment [70]. Fresolimumab is a mAb that targets TGF- $\beta$ and is in ongoing clinical trials [71]. Targeting the tumor microenvironment with mAbs represents a compelling strategy to synergistically inhibit pro-tumorigenic processes when combined with tumor targeted therapy.

Recently, the most successful mAb-based strategies have moved away from targeting tumor antigens and instead focused on targeting immune cells in order to enhance their anti-tumor capabilities. One of the first $\mathrm{mAb}$ approaches to stimulate $\mathrm{T}$ cell anti-tumor immunity was the development of bispecific T Cell Engager (BiTE) antibodies that both target a tumor antigen such as CD19 and the activating receptor, $\mathrm{CD} 3$, on T cells. BiTEs combine direct targeting of tumor cells with recruitment of cytotoxic $\mathrm{T}$ cells into the tumor microenvironment and led to tumor regressions even when administered at doses three orders of magnitude less than the parent $\mathrm{mAb}$ alone [72]. The CD19-CD3 BiTE blinatumomab conferred significant clinical benefit to acute lymphoblastic leukemia patients and was FDA approved in 2017 [73]. Clinical trials are currently underway using BiTEs generated from the widely used anti-HER2 and anti-EGFR mAbs trastuzumab and cetuximab. Other mAb approaches seek to enhance $T$ cell specific immunity against tumor cells by stimulating activating receptors such as 4-1BB, OX40, CD27, CD40, and ICOS (Figure 2). Agonist antibodies towards CD40 stimulate antigen presentation by dendritic cells and mAbs to OX40 and 4-1BB activate T cells while simultaneously dampening the activity of inhibitory $\mathrm{T}$ regulatory cells (Tregs) [74]. mAbs designed to stimulate these activating receptors are in various stages of clinical trials both alone and in combination with other immunotherapy approaches. Additional mAbs that deplete inhibitory Tregs directly, such as daclizumab, which targets CD25 on Tregs, are also undergoing clinical trials [75]. 


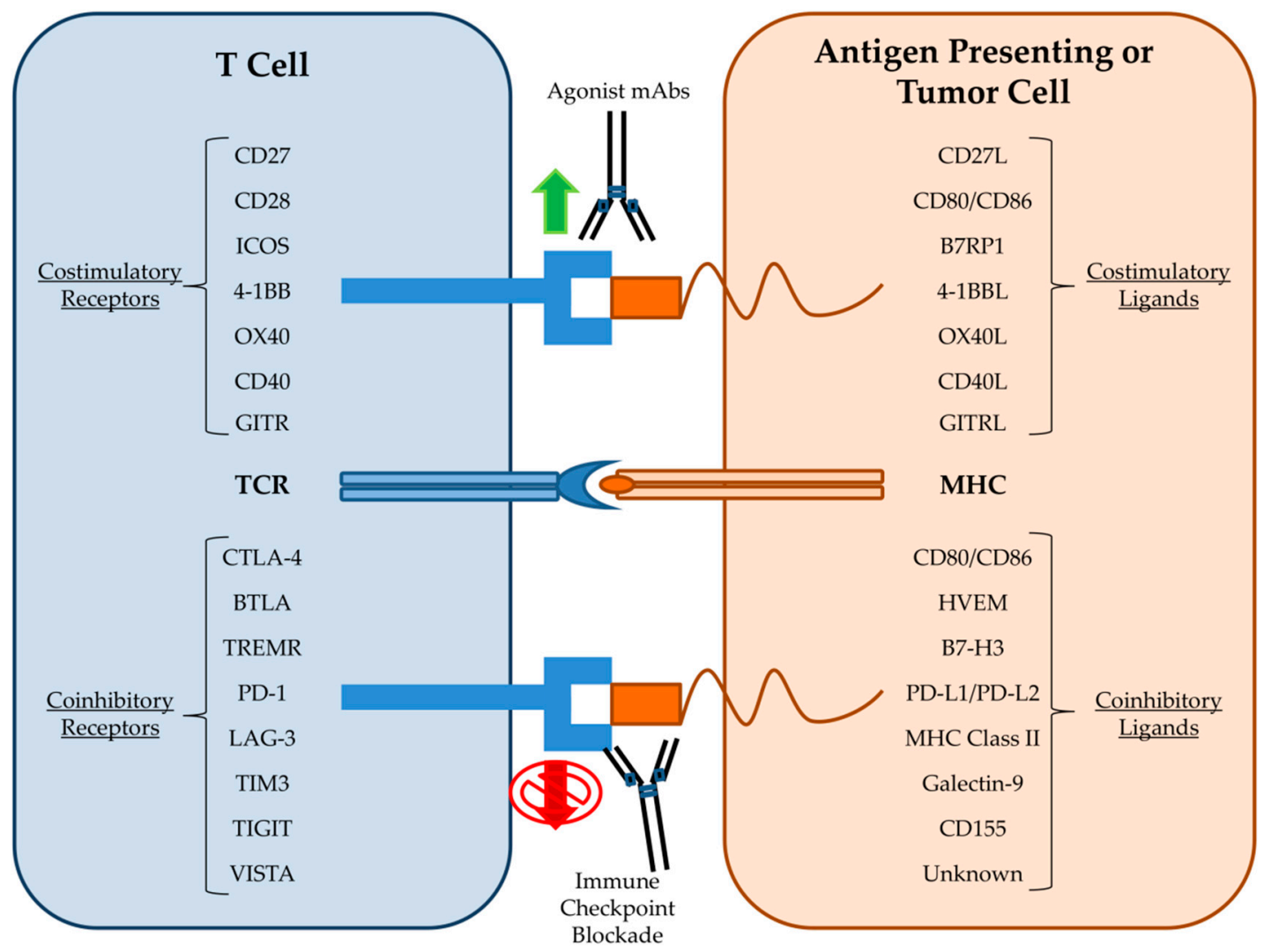

Figure 2. Immune checkpoint targets of monoclonal antibodies.

The most well-known and promising type of mAb therapy for cancer is the blockade of immune checkpoints (Figure 2). Immune cell activation and regulation is a highly complex process that must integrate a variety of costimulatory and coinhibitory signals in order to control immune cell responses to antigen. Immune checkpoints are inhibitory receptors and pathways that are responsible for maintaining self-tolerance and modulating immune responses in order to curtail collateral tissue damage [76]. Cytotoxic T lymphocyte antigen-4 (CTLA-4) was the first T cell checkpoint to be identified. CTLA-4 is mainly expressed by Treg cells but also becomes upregulated on activated T cells where it then outcompetes for binding of the costimulatory ligands CD80 and CD86 [77]. Therefore, it was theorized that blockade of CTLA-4 could indirectly and directly amplify the anti-tumor T cell response by removing inhibitory Tregs and maintaining the activating signals to cytotoxic $\mathrm{T}$ cells respectively. Immune checkpoint blockade (ICB) therapy utilizing mAbs against CTLA-4 was then introduced and following success in animal models was rapidly developed for evaluation in clinical trials [78]. In 2011, the FDA approved the first ICB therapy, the anti-CTLA-4 mAb Ipilimumab, based on promising results from a clinical trial in melanoma patients [79]. Ipilimumab remains the subject of clinical trials for use in additional cancer types [80]. Programmed death receptor-1 (PD-1) is another inhibitory immune checkpoint and is associated with the programmed death pathway in T cells [81]. PD- 1 is expressed on activated CD8+ T cells, Tregs, and activated B cell and natural killer (NK) cells. PD-1 is considered a major regulator of effector $\mathrm{T}$ cell function and is therefore regarded as a key checkpoint target [82]. Tumor cells are known to upregulate the PD-1 ligand, PD-L1, in order to exhaust tumor infiltrating lymphocytes (TILs) [83]. In 2014, the anti-PD-1 mAb nivolumab gained FDA approval for melanoma patients following reports of improved patient outcomes in the CheckMate-037 clinical trial [84]. Subsequent clinical trial successes led to the approval of nivolumab and another anti-PD-1 $\mathrm{mAb}$, pembrolizumab, for the treatment of a wide variety of malignancies [85-87]. Additional mAbs targeting either PD-1 (pidilizumab) or its ligands (durvalumab and atezolizumab) have also performed well in clinical trials [88]. As of this writing, mAbs against the immune checkpoints CTLA-4, PD-1, 
and PD-L1 have received numerous FDA approvals and are used as first-line therapies for the treatment of certain solid tumors [89]. The robust effectiveness of ICB has led to the rapid study of other immune cell inhibitory receptors. Members of the immunoglobulin superfamily such as lymphocyte activation gene 3 (LAG3), T cell immunoglobulin and mucin domain-containing 3 (TIM3), T cell immunoglobulin and immunoreceptor tyrosine-based inhibitory motif domain (TIGIT), and V-domain Ig suppressor of T cell activation (VISTA) are all being explored as potential checkpoint therapeutic targets [90,91]. Importantly, checkpoint blockade also affects other components of the innate immune system such as NK cells. NK cells have the intrinsic ability to kill tumor cells; however, NK cell effector function is modulated by various molecular checkpoints [92]. The blockade of NK cell associated inhibitory receptors such as KIRs are therefore under preclinical investigation [93]. The demonstrable anti-tumor activity and favorable toxicity profile of ICB has cemented mAbs as one of the backbones of cancer therapy.

\section{Mechanisms of Resistance}

Although mAb therapy has proven successful in the treatment of cancer, clinical resistance to these agents continues to be a major issue. Only a minority of patients will respond, with the vast majority developing refractory disease within one year [94-96]. Therapeutic resistance can be considered either innate (primary) or acquired (secondary) with differing mechanisms in each scenario. Innate resistance is mainly due to mutations already present in the tumor cells prior to therapy whereas acquired resistance is the result of immune selection pressure and immunoediting of the tumor during therapy. Preclinical models and clinical trials of mAb therapy have unraveled a myriad of mechanisms of resistance; and they include: Mutations of the antibody target, induction of alternative growth signaling pathways, epithelial to mesenchymal transition (EMT), and impaired effector cell responses.

A limitation of $\mathrm{mAb}$ therapy is that efficacy is dependent on tumor cell expression of the target molecules that are able to be bound by the antibodies. While CD20 gene mutations can confer irreversible resistance to rituximab in lymphoma patients, such mutations were rarely detected at both the initiation of treatment and in cases who relapsed following therapy [97]. A S492R mutation in the EGFR ectodomain imparts resistance to cetuximab but not panitumumab due to their recognition of distinct epitopes [98]. Interestingly, cancer cells expressing EGFR variant III are less sensitive to cetuximab even though the cetuximab binding epitope remains intact [99]. Cell lines chronically exposed to rituximab acquire resistance that is associated with the downregulation of CD20 at both the transcriptional and protein level [100]. Likewise, multiple myeloma patients who received the anti-CD38 monoclonal antibody daratumumab lost CD38 expression in their tumors which correlated with impaired response [101]. Cetuximab-mediated ADCC highly correlates with EGFR surface expression in cell lines but clinical response in patients appear to be independent of tumor EGFR expression level [102,103]. Instead, it has been suggested that mutations and polymorphisms of EGFR are responsible for cetuximab refractory disease. In HNSCC patients that expressed the EGFR-K521 variant ( $40 \%$ of cases) there was reduced affinity of cetuximab to EGFR and efficacy could only be restored with optimization of ADCC [104]. Similarly, KRAS mutation status may affect susceptibility of EGFR overexpressing cancers to ADCC. Cell lines with mutant KRAS had impaired Fas-Fas ligand interactions that are necessary for induction of target cell apoptosis during ADCC [105]. Downregulation of HER2 expression has been proposed as a mechanism of resistance to trastuzumab-mediated ADCC but it remains a controversial issue [106]. Despite conflicting results from in vitro studies there was no reduction found in HER2 expression in breast cancer patients who received trastuzumab [107]. However, it is known that interferon gamma (IFN $\gamma$ ) exposure can lead to HER2 downregulation through STAT1 mediated pathways [108]. Furthermore, trastuzumab-mediated ADCC induces IFN $\gamma$ release from NK cells which leads to a STAT1 dependent downregulation of HER2 expression and concomitant resistance to trastuzumab [109]. It is also known that IFN $\gamma$-induced activation of STAT1 signaling leads to PD-L1 upregulation on the tumor cell surface that confers resistance to NK cell-mediated ADCC [110]. 
Mutations of the antibody target and associated downstream signaling molecules can lead to acquired resistance to $\mathrm{mAb}$ therapy by activating alternative growth or survival signaling pathways. In colorectal cancers, the most frequent mechanism of cetuximab resistance has been reported as genomic alterations in downstream effectors of EGFR such as KRAS, NRAS, BRAF, and PIK3CA [111]. Alterations in these pathways bypass EGFR signaling inhibition by cetuximab. For example, $K R A S$ point mutations are causally linked with acquired resistance to cetuximab treatment in colorectal cancer [112]. In metastatic colorectal cancer patients, activating mutations of the oncogenes $R A S$, $B R A F$, and/or PIK3CA were identified as significant predictors of primary resistance to cetuximab [113]. The resulting enhanced signaling through the downstream MAPK and PI3K/AKT pathways and increased expression of anti-apoptotic BCL-2 proteins is a main mechanism of resistance to mAb induced apoptosis. Furthermore, NRAS mutations that maintain MAPK signaling prevent cetuximab efficacy by preserving the dysregulated ligandless signaling of the pro-tumorigenic EphA2 receptor [114]. Activation of alternative proliferative and survival pathways such as MAPK and eIF5A2 has also been discovered in HNSCC and hepatocellular carcinoma respectively in response to cetuximab $[115,116]$. HER2 mutations in breast cancer can confer resistance to trastuzumab; however, trastuzumab is still able to bind the mutant HER2 [117]. Mutant HER2 leads to dysregulation of the PI3K-AKT signaling pathway and enables trastuzumab resistance through similar anti-apoptotic effector molecules. Furthermore, activating mutations of the PI3K/AKT/mTOR pathway also contribute to trastuzumab resistance in breast cancer [118]. Several studies have reported overexpression of compensatory growth factors such as insulin-like growth factor-I receptor or EGFR as additional potential mechanisms of resistance to trastuzumab [119]. Other signaling pathways implicated in trastuzumab resistance include aberrant activation of the tyrosine kinase SRC, cyclin E/cyclin-dependent kinase (CDK) 2, and cyclin D1/CDK4/6 [120]. In one study of esophageal squamous cell carcinoma, trastuzumab resistant tumor clones had a reduced susceptibility to the perforin-granzyme system [121]. Similarly, X-linked inhibitor of apoptosis protein, which is overexpressed in breast cancer, drove resistance to ADCC mediated by both cetuximab and trastuzumab [122]. In an in vitro study of rituximab-resistant lymphoma clones, major survival pathways such as NF-KB and ERK1/2 became constitutively hyper-activated after treatment, which led to overexpression of factors such as Bcl-2, Bcl-xL, and Mcl-1 that prevented the induction of apoptosis by rituximab [123].

Epithelial to mesenchymal transition (EMT) is a process in which cancer cells lose their epithelial phenotype characterized by cell-to-cell adhesion and instead gain the invasive properties of mesenchymal cells. In preclinical models, EMT was uncovered as a possible mechanism of cetuximab resistance [124]. The induction of EMT was later confirmed to occur early on in head and neck cancer patients receiving cetuximab. Multiple subsequent studies have revealed EMT mediates acquired resistance to cetuximab via a myriad of mechanisms which include loss of EGFR expression [125-127]. Moreover, activation of the EMT pathway is a key predictor of cetuximab resistance in colorectal cancer [128]. In breast cancer, molecular features associated with EMT are linked to primary resistance to trastuzumab [129]. Additionally, sustained treatment of HER2 positive/PTEN negative breast cancers with trastuzumab induced EMT in a subset of patients which conferred acquired resistance [130].

ADCC is considered a main therapeutic mechanism of mAb therapy, and clinical resistance often involves impaired cytotoxic immune effector cell responses. Capuano et al. described a novel mechanism of immune exhaustion, whereby NK cells chronically exposed to rituximab lost their cytotoxic functions due to CD16 ligation [131]. NK cell checkpoints can also regulate ADCC. Poliovirus receptor-like receptors such as TIGIT are known to be involved in trastuzumab-mediated ADCC of cancer cells by NK cells, and blockade of those receptors was able to enhance trastuzumab based responses in breast cancer patients [132]. Finally, NK cell-mediated ADCC is also dependent on the expression of several proteins that are important members of the immune synapse. ADCC is partly dependent on recognition through ICAM-1 and CD18, though this appears to be less important for trastuzumab-mediated ADCC [133]. Cancer cell loss of ligands for the activating NKG2D receptor on NK cells such as MICA and dysregulation of the NKG2A-HLA-E axis can also prevent NK cell 
initiation of ADCC [134]. A recently reported novel mechanism of resistance to ADCC involves the downregulation of multiple cell surface proteins associated with the immune synapse in response to cetuximab and trastuzumab [135].

\section{Combination Therapies}

While $\mathrm{mAb}$ has success as a monotherapy in some patients, treatment paradigms are trending towards employing them as combinations with chemotherapy, radiation, molecularly targeted drugs such as tyrosine kinase inhibitors, other antibodies against the same target, immune checkpoint inhibitors, vaccines, and/or cellular therapies. These many combination strategies are currently undergoing both preclinical investigation and clinical trials and this vast field is more exhaustively covered elsewhere [136]. In this section, we will briefly cover combination therapies involving multiple monoclonal antibodies. It is now widely recognized that the mechanism of action of monoclonal antibodies includes an immune effector cell component. In particular, cetuximab efficacy has been partly attributed to ADCC, which can link innate and adaptive anti-tumor immune responses. Destruction of tumor cells via NK cell-mediated ADCC releases tumor cell specific proteins that when presented by antigen presenting cells to cytotoxic $\mathrm{T}$ cells leads to a more effective anti-tumor response. Head and neck squamous cell carcinoma (HNSCC) patients with durable responses to cetuximab have sustained anti-tumor specific immune responses [137]. With the rise of immune checkpoint inhibitors that can further potentiate such immune responses, it is hypothesized that ICB may act in a synergistic manner with cetuximab. There is growing to support combining anti-PD-1/PD-L1 mAbs with cetuximab in HNSCC patients [138]. Additionally, combinations of either pembrolizumab or avelumab with cetuximab are currently in clinical trials [NCT03082534, NCT03082534]. Likewise, the use of ICB in breast cancer in order to enhance anti-HER2 mAb therapies is a promising strategy. In fact, preclinical evidence suggests that resistance to trastuzumab monotherapy can be overcome by combination with ICB [139]. Based on those results several clinical trials were formed to investigate the relationship between ICB and HER2-targeted mAbs [140]. Preliminary results from the phase I/II PANACEA trial, which tested pembrolizumab combined with trastuzumab in treating breast cancer patients who overexpressed HER2, indicated synergy in the PD-L1+ patient subset [141].

Although there are many immune checkpoints of T-cell activation, each checkpoint has distinct mechanisms. Consequently, ICB combinations that target multiple checkpoints will enhance T cell responses in a synergistic manner. The combination of mAbs targeting CTLA-4 and PD-1 performed significantly better in preclinical mouse models than either antibody alone [142]. Similarly, in metastatic melanoma patients combined therapy of ipilimumab and nivolumab was found to be more effective than either treatment used as a monotherapy [143]. The FDA has since approved the combination of ipilimumab and nivolumab for melanoma. As the first ICB combination with FDA approval, ongoing clinical trials continue to evaluate ipilimumab plus nivolumab in other cancer types.

Anti-PD-1 mAbs are most often used in combinatorial strategies due to their more favorable toxicity profile in contrast to anti-CTLA-4 monoclonal antibodies. The immune checkpoints LAG3 and TIM3 are commonly found co-expressed with PD-1 on exhausted T cells. ICB of LAG3 combined with anti-PD-1 is undergoing clinical trial in glioblastoma (NCT02658981) and other cancers (NCT02460224). There are similar clinical trials for the combination of anti-TIM3 and anti-PD-1 antibodies in liver cancer (NCT03680508) and several other solid tumors (NCT03744468). Another promising combination strategy involves uniting ICB with agonistic antibodies that activate stimulatory receptors. 4-1BB is a costimulatory receptor found on T cells and NK cells and clinical trials that evaluate 4-1BB agonist antibodies in combination with anti-PD-1 mAb therapy are underway (NCT02253992 and NCT02179918). An agonist antibody to the glucocorticoid-induced tumor necrosis factor receptor-related protein (GITR), which promotes T cell activation, also proved to be successful when combined with nivolumab [144]. Additional $\mathrm{mAb}$ combinations that include agonist antibodies to OX40, which only becomes expressed on activated T cells, are the subject of multiple clinical trials (NCT01714739 and NCT01750580). 


\section{Concluding Remarks}

Monoclonal antibody therapy has only recently become one of the major modalities for the treatment of cancer. Many of the mechanisms of action and their clinical relevance remain poorly understood. Despite the notable clinical successes of antibody therapy, therapeutic resistance remains a major challenge. Future studies must focus on analysis of the mechanisms of action of mAbs in order to identify new approaches to increase clinical efficacy. For instance, studies have revealed that ADCC plays a major role in mediating $\mathrm{mAb}$ responses and therefore engineering strategies that augment ADCC activity represents a promising future approach. Combinations of tumor targeted mAbs with ICB have demonstrated that there are several encouraging avenues for maximizing the clinical benefit of $\mathrm{mAb}$ therapy. Additionally, mutations of both the antibody target and any associated signaling pathways are important biomarkers of mAb efficacy and resistance. Future mAb treatment strategies must incorporate inhibitors of these alternative signaling pathways in order to abrogate resistance. Treatment paradigms involving monoclonal antibodies will continue to evolve and have the potential to offer curative therapy for many cancer patients.

Author Contributions: Conceptualization, D.Z. and L.W.; writing-original draft preparation, D.Z.; writing-review and editing, L.W..; funding acquisition, L.W. Both authors have read and agreed to the published version of the manuscript.

Funding: This research was funded by National Institutes of Health, grant number CA50633 and CA51008 (both to LMW).

Conflicts of Interest: The authors declare no conflict of interest.

\section{References}

1. Behring, E.V. Ueber das Zustandekommen der Diphtherie-Immunitüt und der Tetanus-Immunitüt bei Thieren. Dtsch. Med. Wochenschr. 1890. [CrossRef]

2. Van Epps, H.L. How Heidelberger and Avery Sweetened Immunology. J. Exp. Med. 2005, $202,1306$. [CrossRef] [PubMed]

3. Fagraeus, A. Plasma Cellular Reaction and Its Relation to the Formation of Antibodies in Vitro. Nature 1947, 159, 499. [CrossRef] [PubMed]

4. Nossal, G.J.V.; Lederberg, J. Antibody Production by Single Cells. Nature 1958. [CrossRef]

5. Schwaber, J.; Cohen, E.P. Human $\times$ Mouse Somatic Cell Hybrid Clone Secreting Immunoglobulins of Both Parental Types. Nature 1973, 244, 444-447. [CrossRef]

6. Köhler, G.; Milstein, C. Continuous Cultures of Fused Cells Secreting Antibody of Predefined Specificity. Nature 1975, 256, 495-497. [CrossRef]

7. Koprowski, H.; Steplewski, Z.; Herlyn, D.; Herlyn, M. Study of Antibodies against Human Melanoma Produced by Somatic Cell Hybrids. Proc. Natl. Acad. Sci. USA 1978, 75, 3405-3409. [CrossRef]

8. Stashenko, P.; Antman, K.H.; Schlossman, S.F. Serotherapy of a Patient with a Monoclonal Antibody Directed against a Human Lymphoma-Associated Antigen. Cancer Res. 1980, 40, 3147-3154.

9. Shin, S.U.; Morrison, S.L. Production and Properties of Chimeric Antibody Molecules. Methods Enzymol. 1989, 178, 459-476. [CrossRef]

10. Riechmann, L.; Clark, M.; Waldmann, H.; Winter, G. Reshaping Human Antibodies for Therapy. Nature 1988, 332, 323-327. [CrossRef]

11. Nelson, A.L.; Dhimolea, E.; Reichert, J.M. Development Trends for Human Monoclonal Antibody Therapeutics. Nat. Rev. Drug Discov. 2010, 9, 767-774. [CrossRef] [PubMed]

12. Murphy, K. Immunobiology, 9th ed.; Garland Science: New York, NY, USA, 2017. [CrossRef]

13. Weiner, L.M.; Surana, R.; Wang, S. Monoclonal Antibodies: Versatile Platforms for Cancer Immunotherapy. Nat. Rev. Immunol. 2010, 10, 317-327. [CrossRef] [PubMed]

14. Li, S.; Schmitz, K.R.; Jeffrey, P.D.; Wiltzius, J.J.W.; Kussie, P.; Ferguson, K.M. Structural Basis for Inhibition of the Epidermal Growth Factor Receptor by Cetuximab. Cancer Cell 2005, 7, 301-311. [CrossRef] [PubMed] 
15. Patel, D.; Bassi, R.; Hooper, A.; Prewett, M.; Hicklin, D.J.; Kang, X. Anti-Epidermal Growth Factor Receptor Monoclonal Antibody Cetuximab Inhibits EGFR/HER-2 Heterodimerization and Activation. Int. J. Oncol. 2009, 34, 25-32. [CrossRef] [PubMed]

16. Slamon, D.J.; Godolphin, W.; Jones, L.A.; Holt, J.A.; Wong, S.G.; Keith, D.E.; Levin, W.J.; Stuart, S.G.; Udove, J.; Ullrich, A.; et al. Studies of the HER-2/Neu Proto-Oncogene in Human Breast and Ovarian Cancer. Science 1989, 244, 707-712. [CrossRef] [PubMed]

17. Chen, J.S.; Lan, K.; Hung, M.C. Strategies to Target HER2/Neu Overexpression for Cancer Therapy. Drug Resist. Updates 2003, 6, 129-136. [CrossRef]

18. Di Gaetano, N.; Cittera, E.; Nota, R.; Vecchi, A.; Grieco, V.; Scanziani, E.; Botto, M.; Introna, M.; Golay, J. Complement Activation Determines the Therapeutic Activity of Rituximab in Vivo. J. Immunol. 2003, 171, 1581-1587. [CrossRef]

19. Racila, E.; Link, B.K.; Weng, W.K.; Witzig, T.E.; Ansell, S.; Maurer, M.J.; Huang, J.; Dahle, C.; Halwani, A.; Levy, R.; et al. A Polymorphism in the Complement Component C1qA Correlates with Prolonged Response Following Rituximab Therapy of Follicular Lymphoma. Clin. Cancer Res. 2008, 14, 6697-6703. [CrossRef]

20. Coiffier, B.; Lepretre, S.; Pedersen, L.M.; Gadeberg, O.; Fredriksen, H.; Van Oers, M.H.J.; Wooldridge, J.; Kloczko, J.; Holowiecki, J.; Hellmann, A.; et al. Safety and Efficacy of Ofatumumab, a Fully Human Monoclonal Anti-CD20 Antibody, in Patients with Relapsed or Refractory B-Cell Chronic Lymphocytic Leukemia: A Phase 1-2 Study. Blood 2008, 111, 1094-1100. [CrossRef]

21. Gül, N.; Babes, L.; Siegmund, K.; Korthouwer, R.; Bögels, M.; Braster, R.; Vidarsson, G.; Ten Hagen, T.L.M.; Kubes, P.; Van Egmond, M. Macrophages Eliminate Circulating Tumor Cells after Monoclonal Antibody Therapy. J. Clin. Investig. 2014, 124, 812-823. [CrossRef]

22. Möller, E. Contact-Induced Cytotoxicity by Lymphoid Cells Containing Foreign Isoantigens. Science 1965, 147, 873-879. [CrossRef] [PubMed]

23. Teillaud, J.-L. Antibody-Dependent Cellular Cytotoxicity (ADCC). In eLS; John Wiley \& Sons, Ltd: Hoboken, NJ, USA, 2012. [CrossRef]

24. Fanger, M.W.; Shen, L.; Graziano, R.F.; Guyre, P.M. Cytotoxicity Mediated by Human Fc Receptors for IgG. Immunol. Today 1989, 10, 92-99. [CrossRef]

25. Wallace, P.K.; Howell, A.L.; Fanger, M.W. Role of Fc $\gamma$ Receptors in Cancer and Infectious Disease. J. Leukoc. Biol. 1994, 55, 816-826. [CrossRef] [PubMed]

26. Nimmerjahn, F.; Ravetch, J.V. Fc $\gamma$ Receptors as Regulators of Immune Responses. Nat. Rev. Immunol. $2008,8$. [CrossRef] [PubMed]

27. De Saint Basile, G.; Ménasché, G.; Fischer, A. Molecular Mechanisms of Biogenesis and Exocytosis of Cytotoxic Granules. Nat. Rev. Immunol. 2010, 10, 568-579. [CrossRef] [PubMed]

28. Nimmerjahn, F.; Ravetch, J.V. Analyzing Antibody-Fc-Receptor Interactions. Methods Mol. Biol. 2008, 415, 151-162. [CrossRef]

29. Eischen, C.M.; Leibson, P.J. Role for NK-Cell-Associated Fas Ligand in Cell-Mediated Cytotoxicity and Apoptosis. Res. Immunol. 1997, 148, 164-169. [CrossRef]

30. Sondel, P.M.; Alderson, K.L. Clinical Cancer Therapy by NK Cells via Antibody-Dependent Cell-Mediated Cytotoxicity. J. Biomed. Biotechnol. 2011, 2011, 379123. [CrossRef]

31. Clynes, R.A.; Towers, T.L.; Presta, L.G.; Ravetch, J.V. Inhibitory Fc Receptors Modulate in Vivo Cytoxicity against Tumor Targets. Nat. Med. 2000, 6, 443-446. [CrossRef]

32. Minard-colin, V.; Xiu, Y.; Poe, J.C.; Horikawa, M.; Magro, C.M.; Hamaguchi, Y.; Haas, K.M.; Tedder, T.F.; Elisa, C. Lymphoma Depletion during CD20 Immunotherapy in Mice Is Mediated By. Blood 2008, 112, 1205-1213. [CrossRef]

33. De Haij, S.; Jansen, J.H.M.; Boross, P.; Beurskens, F.J.; Bakema, J.E.; Bos, D.L.; Martens, A.; Verbeek, J.S.; Parren, P.W.H.I.; Van De Winkel, J.G.J.; et al. In Vivo Cytotoxicity of Type I CD20 Antibodies Critically Depends on Fc Receptor ITAM Signaling. Cancer Res. 2010, 70, 3209-3217. [CrossRef] [PubMed]

34. Hubert, P.; Heitzmann, A.; Viel, S.; Nicolas, A.; Sastre-Garau, X.; Oppezzo, P.; Pritsch, O.; Osinaga, E.; Amigorena, S. Antibody-Dependent Cell Cytotoxicity Synapses Form in Mice during Tumor-Specific Antibody Immunotherapy. Cancer Res. 2011, 71, 5134-5143. [CrossRef] 
35. Wu, J.; Edberg, J.C.; Redecha, P.B.; Bansal, V.; Guyre, P.M.; Coleman, K.; Salmon, J.E.; Kimberly, R.P. A Novel Polymorphism of Fc $\gamma$ RIIIa (CD16) Alters Receptor Function and Predisposes to Autoimmune Disease. J. Clin. Investig. 1997, 100, 1059-1070. [CrossRef]

36. Bibeau, F.; Lopez-Crapez, E.; Di Fiore, F.; Thezenas, S.; Ychou, M.; Blanchard, F.; Lamy, A.; Penault-Llorca, F.; Frébourg, T.; Michel, P.; et al. Impact of Fc $\gamma$ RIIa-Fc $\gamma$ RIIIa Polymorphisms and KRAS Mutations on the Clinical Outcome of Patients with Metastatic Colorectal Cancer Treated with Cetuximab plus Irinotecan. J. Clin. Oncol. 2009, 27, 1122-1129. [CrossRef]

37. Cartron, G.; Dacheux, L.; Salles, G.; Solal-Celigny, P.; Bardos, P.; Colombat, P.; Watier, H. Therapeutic Activity of Humanized Anti-CD20 Monoclonal Antibody and Polymorphism in IgG Fc Receptor Fc $\gamma$ rIIIa Gene. Blood 2002, 99, 754-758. [CrossRef]

38. Weng, W.K.; Levy, R. Two Immunoglobulin G Fragment C Receptor Polymorphisms Independently Predict Response to Rituximab in Patients with Follicular Lymphoma. J. Clin. Oncol. 2003, 21, 3940-3947. [CrossRef]

39. Hatjiharissi, E.; Xu, L.; Santos, D.D.; Hunter, Z.R.; Ciccarelli, B.T.; Verselis, S.; Modica, M.; Cao, Y.; Manning, R.J.; Leleu, X.; et al. Increased Natural Killer Cell Expression of CD16, Augmented Binding and ADCC Activity to Rituximab among Individuals Expressing the Fc $\gamma$ RIIIa-158 v/v and V/F Polymorphism. Blood 2007, 110, 2561-2564. [CrossRef]

40. Rodríguez, J.; Zarate, R.; Bandres, E.; Boni, V.; Hernández, A.; Sola, J.J.; Honorato, B.; Bitarte, N.; García-Foncillas, J. Fc Gamma Receptor Polymorphisms as Predictive Markers of Cetuximab Efficacy in Epidermal Growth Factor Receptor Downstream-Mutated Metastatic Colorectal Cancer. Eur. J. Cancer 2012, 48, 1774-1780. [CrossRef]

41. Musolino, A.; Naldi, N.; Bortesi, B.; Pezzuolo, D.; Capelletti, M.; Missale, G.; Laccabue, D.; Zerbini, A.; Camisa, R.; Bisagni, G.; et al. Immunoglobulin g Fragment c Receptor Polymorphisms and Clinical Efficacy of Trastuzumab-Based Therapy in Patients with HER-2/Neu-Positive Metastatic Breast Cancer. J. Clin. Oncol. 2008, 26, 1789-1796. [CrossRef]

42. Boero, S.; Morabito, A.; Banelli, B.; Cardinali, B.; Dozin, B.; Lunardi, G.; Piccioli, P.; Lastraioli, S.; Carosio, R.; Salvi, S.; et al. Analysis of in Vitro ADCC and Clinical Response to Trastuzumab: Possible Relevance of Fc $\gamma$ RIIIA/Fc $\gamma$ RIIA Gene Polymorphisms and HER-2 Expression Levels on Breast Cancer Cell Lines. J. Transl. Med. 2015, 13, 1-14. [CrossRef] [PubMed]

43. Siebert, N.; Jensen, C.; Troschke-Meurer, S.; Zumpe, M.; Jüttner, M.; Ehlert, K.; Kietz, S.; Müller, I.; Lode, H.N. Neuroblastoma Patients with High-Affinity FCGR2A, -3A and Stimulatory KIR 2DS2 Treated by Long-Term Infusion of Anti-GD2 Antibody Ch14.18/CHO Show Higher ADCC Levels and Improved Event-Free Survival. Oncoimmunology 2016, 5, 1-14. [CrossRef] [PubMed]

44. Arnould, L.; Gelly, M.; Penault-Llorca, F.; Benoit, L.; Bonnetain, F.; Migeon, C.; Cabaret, V.; Fermeaux, V.; Bertheau, P.; Garnier, J.; et al. Trastuzumab-Based Treatment of HER2-Positive Breast Cancer: An Antibody-Dependent Cellular Cytotoxicity Mechanism? Br. J. Cancer 2006, 94, 259-267. [CrossRef]

45. Vermi, W.; Micheletti, A.; Finotti, G.; Tecchio, C.; Calzetti, F.; Costa, S.; Bugatti, M.; Calza, S.; Agostinelli, C.; Pileri, S.; et al. Slan + Monocytes and Macrophages Mediate CD20-Dependent B Cell Lymphoma Elimination via ADCC and ADCP. Cancer Res. 2018, 78, 3544-3559. [CrossRef]

46. de Weers, M.; Tai, Y.-T.; van der Veer, M.S.; Bakker, J.M.; Vink, T.; Jacobs, D.C.H.; Oomen, L.A.; Peipp, M.; Valerius, T.; Slootstra, J.W.; et al. Daratumumab, a Novel Therapeutic Human CD38 Monoclonal Antibody, Induces Killing of Multiple Myeloma and Other Hematological Tumors. J. Immunol. 2011, 186, 1840-1848. [CrossRef]

47. Ferris, R.L.; Jaffee, E.M.; Ferrone, S. Tumor Antigen-Targeted, Monoclonal Antibody-Based Immunotherapy: Clinical Response, Cellular Immunity, and Immunoescape. J. Clin. Oncol. 2010, 28, 4390-4399. [CrossRef]

48. Liu, Z.; Gunasekaran, K.; Wang, W.; Razinkov, V.; Sekirov, L.; Leng, E.; Sweet, H.; Foltz, I.; Howard, M.; Rousseau, A.M.; et al. Asymmetrical Fc Engineering Greatly Enhances Antibodydependent Cellular Cytotoxicity (ADCC) Effector Function and Stability of the Modified Antibodies. J. Biol. Chem. 2014, 289, 3571-3590. [CrossRef] 
49. Umaña, P.; Jean-Mairet, J.; Moudry, R.; Amstutz, H.; Bailey, J.E. Engineered Glycoforms of an Antineuroblastoma IgG1 with Optimized Antibody-Dependent Cellular Cytotoxic Activity. Nat. Biotechnol. 1999, 17, 176-180. [CrossRef]

50. Davies, J.; Jiang, L.; Pan, L.Z.; Labarre, M.J.; Anderson, D.; Reff, M. Expression of GnTIII in a Recombinant Anti-CD20 CHO Production Cell Line: Expression of Antibodies with Altered Glycoforms Leads to an Increase in ADCC through Higher Affinity for Fc $\gamma$ RIII. Biotechnol. Bioeng. 2001, 74, 288-294. [CrossRef]

51. Shields, R.L.; Lai, J.; Keck, R.; O’Connell, L.Y.; Hong, K.; Gloria Meng, Y.; Weikert, S.H.A.; Presta, L.G. Lack of Fucose on Human IgG1 N-Linked Oligosaccharide Improves Binding to Human Fc $\gamma$ RIII and Antibody-Dependent Cellular Toxicity. J. Biol. Chem. 2002, 277, 26733-26740. [CrossRef]

52. Ishida, T.; Joh, T.; Uike, N.; Yamamoto, K.; Utsunomiya, A.; Yoshida, S.; Saburi, Y.; Miyamoto, T.; Takemoto, S.; Suzushima, H.; et al. Defucosylated Anti-CCR4 Monoclonal Antibody (KW-0761) for Relapsed Adult T-Cell Leukemia-Lymphoma: A Multicenter Phase II Study. J. Clin. Oncol. 2012, 30, 837-842. [CrossRef]

53. Finn, O.J. Human Tumor Antigens Yesterday, Today, and Tomorrow. Cancer Immunol. Res. 2017, 5, 347-354. [CrossRef] [PubMed]

54. Maloney, D.G.; Grillo-López, A.J.; White, C.A.; Bodkin, D.; Schilder, R.J.; Neidhart, J.A.; Janakiraman, N.; Foon, K.A.; Liles, T.M.; Dallaire, B.K.; et al. IDEC-C2B8 (Rituximab) Anti-CD20 Monoclonal Antibody Therapy in Patients with Relapsed Low-Grade Non-Hodgkin's Lymphoma. Blood 1997, 90, 2188-2195. [CrossRef] [PubMed]

55. Rimawi, M.F.; Schiff, R.; Osborne, C.K. Targeting HER2 for the Treatment of Breast Cancer. Annu. Rev. Med. 2015, 66, 111-128. [CrossRef] [PubMed]

56. Mendelsohn, J. The Epidermal Growth Factor Receptor as a Target for Therapy with Antireceptor Monoclonal Antibodies. Semin. Cancer Biol. 1990, 1, 339-344.

57. Indications and Year of First Approval for Each Antibody Were Accessed Using the FDA Drug Database. Available online: https://www.accessdata.fda.gov/scripts/cder/daf/ (accessed on 21 May 2020).

58. Chari, R.V.J. Targeted Cancer Therapy: Conferring Specificity to Cytotoxic Drugs. Acc. Chem. Res. 2008, 41, 98-107. [CrossRef]

59. Younes, A.; Bartlett, N.L.; Leonard, J.P.; Kennedy, D.A.; Lynch, C.M.; Sievers, E.L.; Forero-Torres, A. Brentuximab Vedotin (SGN-35) for Relapsed CD30-Positive Lymphomas. N. Engl. J. Med. 2010, 363, 1812-1821. [CrossRef]

60. Verma, S.; Miles, D.; Gianni, L.; Krop, I.E.; Welslau, M.; Baselga, J.; Pegram, M.; Oh, D.Y.; Diéras, V.; Guardino, E.; et al. Trastuzumab Emtansine for HER2-Positive Advanced Breast Cancer. N. Engl. J. Med. 2012, 18, 732-742. [CrossRef]

61. Chau, C.H.; Steeg, P.S.; Figg, W.D. Antibody-Drug Conjugates for Cancer. Lancet 2019, 394, $793-804$. [CrossRef]

62. Thomas, A.; Teicher, B.A.; Hassan, R. Antibody-Drug Conjugates for Cancer Therapy. Lancet Oncol. 2016, 17, e254-e262. [CrossRef]

63. Becker, N.; Benhar, I. Antibody-Based Immunotoxins for the Treatment of Cancer. Antibodies 2012, 1, 39-69. [CrossRef]

64. Dhillon, S. Moxetumomab Pasudotox: First Global Approval. Drugs 2018, 78, 1763-1767. [CrossRef]

65. Steiner, M.; Neri, D. Antibody-Radionuclide Conjugates for Cancer Therapy: Historical Considerations and New Trends. Clin. Cancer Res. 2011, 17, 6406-6416. [CrossRef]

66. Ellis, L.M.; Hicklin, D.J. VEGF-Targeted Therapy: Mechanisms of Anti-Tumour Activity. Nat. Rev. Cancer 2008, 8, 579-591. [CrossRef] [PubMed]

67. Krupitskaya, Y.; Wakelee, H.A. Ramucirumab, a Fully Human MAb to the Transmembrane Signaling Tyrosine Kinase VEGFR-2 for the Potential Treatment of Cancer. Curr. Opin. Investig. Drugs 2009, 10, 597-605. [PubMed]

68. Wu, Y.; Zhong, Z.; Huber, J.; Bassi, R.; Finnerty, B.; Corcoran, E.; Li, H.; Navarro, E.; Balderes, P.; Jimenez, X.; et al. Anti-Vascular Endothelial Growth Factor Receptor-1 Antagonist Antibody as a Therapeutic Agent for Cancer. Clin. Cancer Res. 2006, 12, 6573-6584. [CrossRef] [PubMed] 
69. Shen, J.; Vil, M.D.; Prewett, M.; Damoci, C.; Zhang, H.; Li, H.; Jimenez, X.; Deevi, D.S.; Iacolina, M.; Kayas, A.; et al. Development of a Fully Human Anti-PDGFR $\beta$ Antibody That Suppresses Growth of Human Tumor Xenografts and Enhances Antitumor Activity of an Anti-VEGFR2 Antibody. Neoplasia 2009, 11, 594-604. [CrossRef]

70. Colak, S.; ten Dijke, P. Targeting TGF- $\beta$ Signaling in Cancer. Trends Cancer 2017, 3, 56-71. [CrossRef] [PubMed]

71. Grütter, C.; Wilkinson, T.; Turner, R.; Podichetty, S.; Finch, D.; McCourt, M.; Loning, S.; Jermutus, L.; Grütter, M.G. A Cytokine-Neutralizing Antibody as a Structural Mimetic of 2 Receptor Interactions. Proc. Natl. Acad. Sci. USA 2008, 105, 20251-20256. [CrossRef] [PubMed]

72. Lutterbuese, R.; Raum, T.; Kischel, R.; Hoffmann, P.; Mangold, S.; Rattel, B.; Friedrich, M.; Thomas, O.; Lorenczewski, G.; Rau, D.; et al. T Cell-Engaging BiTE Antibodies Specific for EGFR Potently Eliminate KRAS- and BRAF-Mutated Colorectal Cancer Cells. Proc. Natl. Acad. Sci. USA 2010, 107, 12605-12610. [CrossRef]

73. Kantarjian, H.; Stein, A.; Gökbuget, N.; Fielding, A.K.; Schuh, A.C.; Ribera, J.-M.; Wei, A.; Dombret, H.; Foà, R.; Bassan, R.; et al. Blinatumomab versus Chemotherapy for Advanced Acute Lymphoblastic Leukemia. N. Engl. J. Med. 2017, 376, 836-847. [CrossRef]

74. Redman, J.M.; Hill, E.M.; AlDeghaither, D.; Weiner, L.M. Mechanisms of Action of Therapeutic Antibodies for Cancer. Mol. Immunol. 2015, 67, 28-45. [CrossRef] [PubMed]

75. Rech, A.J.; Vonderheide, R.H. Clinical Use of Anti-CD25 Antibody Daclizumab to Enhance Immune Responses to Tumor Antigen Vaccination by Targeting Regulatory T Cells. Ann. N. Y. Acad. Sci. 2009, 1174, 99-106. [CrossRef]

76. Pardoll, D.M. The Blockade of Immune Checkpoints in Cancer Immunotherapy. Nat. Rev. Cancer 2012. [CrossRef] [PubMed]

77. Qureshi, O.S.; Zheng, Y.; Nakamura, K.; Attridge, K.; Manzotti, C.; Schmidt, E.M.; Baker, J.; Jeffery, L.E.; Kaur, S.; Briggs, Z.; et al. Trans-Endocytosis of CD80 and CD86: A Molecular Basis for the Cell-Extrinsic Function of CTLA-4. Science 2011, 332, 600-603. [CrossRef] [PubMed]

78. Leach, D.R.; Krummel, M.F.; Allison, J.P. Enhancement of Antitumor Immunity by CTLA-4 Blockade. Science 1996, 271, 1734-1736. [CrossRef]

79. Hodi, F.S.; O’Day, S.J.; McDermott, D.F.; Weber, R.W.; Sosman, J.A.; Haanen, J.B.; Gonzalez, R.; Robert, C.; Schadendorf, D.; Hassel, J.C.; et al. Improved Survival with Ipilimumab in Patients with Metastatic Melanoma. N. Engl. J. Med. 2010, 363, 711-723. [CrossRef]

80. Topalian, S.L.; Drake, C.G.; Pardoll, D.M. Immune Checkpoint Blockade: A Common Denominator Approach to Cancer Therapy. Cancer Cell 2015, 27, 450-461. [CrossRef]

81. Nishimura, H.; Nose, M.; Hiai, H.; Minato, N.; Honjo, T. Development of Lupus-like Autoimmune Diseases by Disruption of the PD-1 Gene Encoding an ITIM Motif-Carrying Immunoreceptor. Immunity 1999, 11, 141-151. [CrossRef]

82. Topalian, S.L.; Hodi, F.S.; Brahmer, J.R.; Gettinger, S.N.; Smith, D.C.; McDermott, D.F.; Powderly, J.D.; Carvajal, R.D.; Sosman, J.A.; Atkins, M.B.; et al. Safety, Activity, and Immune Correlates of Anti-PD-1 Antibody in Cancer. N. Engl. J. Med. 2012, 366, 2443-2454. [CrossRef]

83. Sznol, M.; Chen, L. Antagonist Antibodies to PD-1 and B7-H1 (PD-L1) in the Treatment of Advanced Human Cancer. Clin. Cancer Res. 2013, 19, 1021-1034. [CrossRef]

84. Weber, J.S.; D’Angelo, S.P.; Minor, D.; Hodi, F.S.; Gutzmer, R.; Neyns, B.; Hoeller, C.; Khushalani, N.I.; Miller, W.H.; Lao, C.D.; et al. Nivolumab versus Chemotherapy in Patients with Advanced Melanoma Who Progressed after Anti-CTLA-4 Treatment (CheckMate 037): A Randomised, Controlled, Open-Label, Phase 3 Trial. Lancet Oncol. 2015, 16, 375-384. [CrossRef]

85. Brahmer, J.; Reckamp, K.L.; Baas, P.; Crinò, L.; Eberhardt, W.E.E.; Poddubskaya, E.; Antonia, S.; Pluzanski, A.; Vokes, E.E.; Holgado, E.; et al. Nivolumab versus Docetaxel in Advanced Squamous-Cell Non-Small-Cell Lung Cancer. N. Engl. J. Med. 2015, 373, 123-135. [CrossRef] [PubMed]

86. Motzer, R.J.; Escudier, B.; McDermott, D.F.; George, S.; Hammers, H.J.; Srinivas, S.; Tykodi, S.S.; Sosman, J.A.; Procopio, G.; Plimack, E.R.; et al. Nivolumab versus Everolimus in Advanced Renal-Cell Carcinoma. N. Engl. J. Med. 2015, 373, 1803-1813. [CrossRef] [PubMed] 
87. Ribas, A.; Puzanov, I.; Dummer, R.; Schadendorf, D.; Hamid, O.; Robert, C.; Hodi, F.S.; Schachter, J.; Pavlick, A.C.; Lewis, K.D.; et al. Pembrolizumab versus Investigator-Choice Chemotherapy for Ipilimumab-Refractory Melanoma (KEYNOTE-002): A Randomised, Controlled, Phase 2 Trial. Lancet Oncol. 2015, 16, 908-918. [CrossRef]

88. Abdin, S.M.; Zaher, D.M.; Arafa, E.S.A.; Omar, H.A. Tackling Cancer Resistance by Immunotherapy: Updated Clinical Impact and Safety of PD-1/PD-L1 Inhibitors. Cancers 2018, 10, 32. [CrossRef] [PubMed]

89. Hargadon, K.M.; Johnson, C.E.; Williams, C.J. Immune Checkpoint Blockade Therapy for Cancer: An Overview of FDA-Approved Immune Checkpoint Inhibitors. Int. Immunopharmacol. 2018, 62, 29-39. [CrossRef] [PubMed]

90. Anderson, A.C.; Joller, N.; Kuchroo, V.K. Lag-3, Tim-3, and TIGIT: Co-Inhibitory Receptors with Specialized Functions in Immune Regulation. Immunity 2016, 44, 989-1004. [CrossRef]

91. Ni, L.; Dong, C. New Checkpoints in Cancer Immunotherapy. Immunol. Rev. 2017, 276, 52-65. [CrossRef]

92. Kim, N.; Kim, H.S. Targeting Checkpoint Receptors and Molecules for Therapeutic Modulation of Natural Killer Cells. Front. Immunol. 2018, 9, 1-10. [CrossRef]

93. Kohrt, H.E.; Thielens, A.; Marabelle, A.; Sagiv-Barfi, I.; Sola, C.; Chanuc, F.; Fuseri, N.; Bonnafous, C.; Czerwinski, D.; Rajapaksa, A.; et al. Anti-KIR Antibody Enhancement of Anti-Lymphoma Activity of Natural Killer Cells as Monotherapy and in Combination with Anti-CD20 Antibodies. Blood 2014, 123, 678-686. [CrossRef]

94. McLaughlin, P.; Grillo-López, A.J.; Link, B.K.; Levy, R.; Czuczman, M.S.; Williams, M.E.; Heyman, M.R.; Bence-Bruckler, I.; White, C.A.; Cabanillas, F.; et al. Rituximab Chimeric Anti-CD20 Monoclonal Antibody Therapy for Relapsed Indolent Lymphoma: Half of Patients Respond to a Four-Dose Treatment Program. J. Clin. Oncol. 1998, 16, 2825-2833. [CrossRef]

95. Benavente, S.; Huang, S.; Armstrong, E.A.; Chi, A.; Hsu, K.T.; Wheeler, D.L.; Harari, P.M. Establishment and Characterization of a Model of Acquired Resistance to Epidermal Growth Factor Receptor Targeting Agents in Human Cancer Cells. Clin. Cancer Res. 2009, 15, 1585-1592. [CrossRef] [PubMed]

96. Ahmad, A. Current Updates on Trastuzumab Resistance in HER2 Overexpressing Breast Cancers. In Advances in Experimental Medicine and Biology; Springer: Cham, Switzerland, 2019; Volume 1152, pp. 217-228. [CrossRef]

97. Mishima, Y.; Terui, Y.; Takeuchi, K.; Matsumoto-Mishima, Y.; Matsusaka, S.; Utsubo-Kuniyoshi, R.; Hatake, K. The Identification of Irreversible Rituximab-Resistant Lymphoma Caused by CD20 Gene Mutations. Blood Cancer J. 2011, 1, e15-e18. [CrossRef] [PubMed]

98. Sickmier, E.A.; Kurzeja, R.J.M.; Michelsen, K.; Vazir, M.; Yang, E.; Tasker, A.S. The Panitumumab EGFR Complex Reveals a Binding Mechanism That Overcomes Cetuximab Induced Resistance. PLoS ONE 2016, 11, e0163366. [CrossRef] [PubMed]

99. Patel, D.; Lahiji, A.; Patel, S.; Franklin, M.; Jimenez, X.; Hicklin, D.J.; Kang, X. Monoclonal Antibody Cetuximab Binds to and Down-Regulates Constitutively Activated Epidermal Growth Factor Receptor VIII on the Cell Surface. Anticancer Res. 2007, 27, 3355-3366. [PubMed]

100. Czuczman, M.S.; Olejniczak, S.; Gowda, A.; Kotowski, A.; Binder, A.; Kaur, H.; Knight, J.; Starostik, P.; Deans, J.; Hernandez-Ilizaliturri, F.J. Acquirement of Rituximab Resistance in Lymphoma Cell Lines Is Associated with Both Global CD20 Gene and Protein Down-Regulation Regulated at the Pretranscriptional and Posttranscriptional Levels. Clin. Cancer Res. 2008, 14, 1561-1570. [CrossRef]

101. Nijhof, I.S.; Casneuf, T.; Van Velzen, J.; Van Kessel, B.; Axel, A.E.; Syed, K.; Groen, R.W.J.; Van Duin, M.; Sonneveld, P.; Minnema, M.C.; et al. CD38 Expression and Complement Inhibitors Affect Response and Resistance to Daratumumab Therapy in Myeloma. Blood 2016, 128, 959-970. [CrossRef]

102. Seo, Y.; Ishii, Y.; Ochiai, H.; Fukuda, K.; Akimoto, S.; Hayashida, T.; Okabayashi, K.; Tsuruta, M.; Hasegawa, H.; Kitagawa, Y. Cetuximab-Mediated ADCC Activity Is Correlated with the Cell Surface Expression Level of EGFR but Not with the KRAS/BRAF Mutational Status in Colorectal Cancer. Oncol. Rep. 2014, 31, 2115-2122. [CrossRef]

103. Lee, S.C.; López-Albaitero, A.; Ferris, R.L. Immunotherapy of Head and Neck Cancer Using Tumor Antigen-Specific Monoclonal Antibodies. Curr. Oncol. Rep. 2009, 11, 156-162. [CrossRef] 
104. Braig, F.; Kriegs, M.; Voigtlaender, M.; Habel, B.; Grob, T.; Biskup, K.; Blanchard, V.; Sack, M.; Thalhammer, A.; Batalla, I.B.; et al. Cetuximab Resistance in Head and Neck Cancer Is Mediated by EGFR-K521 Polymorphism. Cancer Res. 2017, 77, 1188-1199. [CrossRef]

105. Nakadate, Y.; Kodera, Y.; Kitamura, Y.; Shirasawa, S.; Tachibana, T.; Tamura, T.; Koizumi, F. KRAS Mutation Confers Resistance to Antibody-Dependent Cellular Cytotoxicity of Cetuximab against Human Colorectal Cancer Cells. Int. J. Cancer 2014, 134, 2146-2155. [CrossRef] [PubMed]

106. Valabrega, G.; Montemurro, F.; Aglietta, M. Trastuzumab: Mechanism of Action, Resistance and Future Perspectives in HER2-Overexpressing Breast Cancer. Ann. Oncol. 2007, 18, 977-984. [CrossRef]

107. Gennari, R.; Menard, S.; Fagnoni, F.; Ponchio, L.; Scelsi, M.; Tagliabue, E.; Castiglioni, F.; Villani, L.; Magalotti, C.; Gibelli, N.; et al. Pilot Study of the Mechanism of Action of Preoperative Trastuzumab in Patients with Primary Operable Breast Tumors Overexpressing HER2. Clin. Cancer Res. 2004, 10, 5650-5655. [CrossRef]

108. Kominsky, S.L.; Hobeika, A.C.; Lake, F.A.; Torres, B.A.; Johnson, H.M. Down-Regulation of Neu/HER-2 by Interferon- $\gamma$ in Prostate Cancer Cells. Cancer Res. 2000, 60, 3904-3908.

109. Shi, Y.; Fan, X.; Meng, W.; Deng, H.; Zhang, N.; An, Z. Engagement of Immune Effector Cells by Trastuzumab Induces HER2/ERBB2 Downregulation in Cancer Cells through STAT1 Activation. Breast Cancer Res. 2014, 16, 1-11. [CrossRef] [PubMed]

110. Bellucci, R.; Martin, A.; Bommarito, D.; Wang, K.; Hansen, S.H.; Freeman, G.J.; Ritz, J. Interferon- $\gamma$-Induced Activation of JAK1 and JAK2 Suppresses Tumor Cell Susceptibility to NK Cells through Upregulation of PD-L1 Expression. Oncoimmunology 2015, 4, 1-10. [CrossRef]

111. Sforza, V.; Martinelli, E.; Ciardiello, F.; Gambardella, V.; Napolitano, S.; Martini, G.; Corte, C.D.; Cardone, C.; Ferrara, M.L.; Reginelli, A.; et al. Mechanisms of Resistance to Anti-Epidermal Growth Factor Receptor Inhibitors in Metastatic Colorectal Cancer. World J. Gastroenterol. 2016, 22, 6345-6361. [CrossRef] [PubMed]

112. Misale, S.; Yaeger, R.; Hobor, S.; Scala, E.; Janakiraman, M.; Liska, D.; Valtorta, E.; Schiavo, R.; Buscarino, M.; Siravegna, G.; et al. Emergence of KRAS Mutations and Acquired Resistance to Anti-EGFR Therapy in Colorectal Cancer. Nature 2012, 486, 532-536. [CrossRef]

113. Kasper, S.; Reis, H.; Ziegler, S.; Nothdurft, S.; Mueller, A.; Goetz, M.; Wiesweg, M.; Phasue, J.; Ting, S.; Wieczorek, S.; et al. Molecular Dissection of Effector Mechanisms of RAS-Mediated Resistance to Anti-EGFR Antibody Therapy. Oncotarget 2017, 8, 45898-45917. [CrossRef]

114. Cuyàs, E.; Queralt, B.; Martin-Castillo, B.; Bosch-Barrera, J.; Menendez, J.A. EphA2 Receptor Activation with Ephrin-A1 Ligand Restores Cetuximab Efficacy in NRAS-Mutant Colorectal Cancer Cells. Oncol. Rep. 2017, 38, 263-270. [CrossRef]

115. Ozawa, H.; Ranaweera, R.S.; Izumchenko, E.; Makarev, E.; Zhavoronkov, A.; Fertig, E.J.; Howard, J.D.; Markovic, A.; Bedi, A.; Ravi, R.; et al. SMAD4 Loss Is Associated with Cetuximab Resistance and Induction of MAPK/JNK Activation in Head and Neck Cancer Cells. Clin. Cancer Res. 2017, 23, 5162-5175. [CrossRef] [PubMed]

116. Xue, F.; Liu, Y.; Chu, H.; Wen, Y.; Yan, L.; Tang, Q.; Xiao, E.; Zhang, D.; Zhang, H. EIF5A2 Is an Alternative Pathway for Cell Proliferation in Cetuximab-Treated Epithelial Hepatocellular Carcinoma. Am. J. Transl. Res. 2016, 8, 4670-4681. [PubMed]

117. Kong, X.; Zhang, K.; Wang, X.; Yang, X.; Li, Y.; Zhai, J.; Xing, Z.; Qi, Y.; Gao, R.; Feng, X.; et al. Mechanism of Trastuzumab Resistance Caused by HER-2 Mutation in Breast Carcinomas. Cancer Manag. Res. 2019, 11, 5971-5982. [CrossRef] [PubMed]

118. Chandarlapaty, S.; Sakr, R.A.; Giri, D.; Patil, S.; Heguy, A.; Morrow, M.; Modi, S.; Norton, L.; Rosen, N.; Hudis, C.; et al. Frequent Mutational Activation of the PI3K-AKT Pathway in Trastuzumab-Resistant Breast Cancer. Clin. Cancer Res. 2012, 18, 6784-6791. [CrossRef] [PubMed]

119. Ritter, C.A.; Perez-Torres, M.; Rinehart, C.; Guix, M.; Dugger, T.; Engelman, J.A.; Arteaga, C.L. Human Breast Cancer Cells Selected for Resistance to Trastuzumab in Vivo Overexpress Epidermal Growth Factor Receptor and ErbB Ligands and Remain Dependent on the ErbB Receptor Network. Clin. Cancer Res. 2007, 13, 4909-4919. [CrossRef] [PubMed] 
120. Vernieri, C.; Milano, M.; Brambilla, M.; Mennitto, A.; Maggi, C.; Cona, M.S.; Prisciandaro, M.; Fabbroni, C.; Celio, L.; Mariani, G.; et al. Resistance Mechanisms to Anti-HER2 Therapies in HER2-Positive Breast Cancer: Current Knowledge, New Research Directions and Therapeutic Perspectives. Crit. Rev. Oncol. Hematol. 2019, 139, 53-66. [CrossRef]

121. Kawaguchi, Y.; Kono, K.; Mizukami, Y.; Mimura, K.; Fujii, H. Mechanisms of Escape from Trastuzumab-Mediated ADCC in Esophageal Squamous Cell Carcinoma: Relation to Susceptibility to Perforin-Granzyme. Anticancer Res. 2009, 29, 2137-2146.

122. Evans, M.K.; Sauer, S.J.; Nath, S.; Robinson, T.J.; Morse, M.A.; Devi, G.R. X-Linked Inhibitor of Apoptosis Protein Mediates Tumor Cell Resistance to Antibody-Dependent Cellular Cytotoxicity. Cell Death Dis. 2016, 7, e2073. [CrossRef]

123. Jazirehi, A.R.; Vega, M.I.; Bonavida, B. Development of Rituximab-Resistant Lymphoma Clones with Altered Cell Signaling and Cross-Resistance to Chemotherapy. Cancer Res. 2007, 67, 1270-1281. [CrossRef]

124. Schmitz, S.; Bindea, G.; Albu, R.I.; Mlecnik, B.; Machiels, J.P. Cetuximab Promotes Epithelial to Mesenchymal Transition and Cancer Associated Fibroblasts in Patients with Head and Neck Cancer. Oncotarget 2015, 6, 34288-34299. [CrossRef]

125. Kimura, I.; Kitahara, H.; Ooi, K.; Kato, K.; Noguchi, N.; Yoshizawa, K.; Nakamura, H.; Kawashiri, S. Loss of Epidermal Growth Factor Receptor Expression in Oral Squamous Cell Carcinoma Is Associated with Invasiveness and Epithelial-Mesenchymal Transition. Oncol. Lett. 2016, 11, 201-207. [CrossRef]

126. Hsu, D.S.S.; Hwang, W.L.; Yuh, C.H.; Chu, C.H.; Ho, Y.H.; Chen, P.B.; Lin, H.S.; Lin, H.K.; Wu, S.P.; Lin, C.Y.; et al. Lymphotoxin- $\beta$ Interacts with Methylated EGFR to Mediate Acquired Resistance to Cetuximab in Head and Neck Cancer. Clin. Cancer Res. 2017, 23, 4388-4401. [CrossRef] [PubMed]

127. Cheng, H.; Fertig, E.J.; Ozawa, H.; Hatakeyama, H.; Howard, J.D.; Perez, J.; Considine, M.; Thakar, M.; Ranaweera, R.; Krigsfeld, G.; et al. Decreased SMAD4 Expression Is Associated with Induction of Epithelial-to-Mesenchymal Transition and Cetuximab Resistance in Head and Neck Squamous Cell Carcinoma. Cancer Biol. Ther. 2015, 16, 1252-1258. [CrossRef] [PubMed]

128. Oliveras-Ferraros, C.; Vazquez-Martin, A.; Cufí, S.; Queralt, B.; Báez, L.; Guardeño, R.; Hernández-Yagü e, X.; Martin-Castillo, B.; Brunet, J.; Menendez, J.A. Stem Cell Property Epithelial-to-Mesenchymal Transition Is a Core Transcriptional Network for Predicting Cetuximab (ErbituxTM) Efficacy in KRAS Wild-Type Tumor Cells. J. Cell. Biochem. 2011, 112, 10-29. [CrossRef] [PubMed]

129. Oliveras-Ferraros, C.; Corominas-Faja, B.; Vazquez-Martin, S.C.A.; Martin-Castillo, B.; Iglesias, J.M.; López-Bonet, E.; Martin, Á.G.; Menendez, J.A. Epithelial-to-Mesenchymal Transition (EMT) Confers Primary Resistance to Trastuzumab (Herceptin). Cell Cycle 2012, 11, 4020-4032. [CrossRef] [PubMed]

130. Burnett, J.P.; Korkaya, H.; Ouzounova, M.D.; Jiang, H.; Conley, S.J.; Newman, B.W.; Sun, L.; Connarn, J.N.; Chen, C.S.; Zhang, N.; et al. Trastuzumab Resistance Induces EMT to Transform HER2 + PTEN' to a Triple Negative Breast Cancer That Requires Unique Treatment Options. Sci. Rep. 2015, 5, 15821. [CrossRef]

131. Capuano, C.; Romanelli, M.; Pighi, C.; Cimino, G.; Rago, A.; Molfetta, R.; Paolini, R.; Santoni, A.; Galandrini, R. Anti-CD20 Therapy Acts via Fc $\gamma$ RIIIA to Diminish Responsiveness of Human Natural Killer Cells. Cancer Res. 2015, 75, 4097-4108. [CrossRef]

132. Xu, F.; Sunderland, A.; Zhou, Y.; Schulick, R.D.; Edil, B.H.; Zhu, Y. Blockade of CD112R and TIGIT Signaling Sensitizes Human Natural Killer Cell Functions. Cancer Immunol. Immunother. 2017, 66, 1367-1375. [CrossRef]

133. Cooley, S.; Burns, L.J.; Repka, T.; Miller, J.S. Natural Killer Cell Cytotoxicity of Breast Cancer Targets Is Enhanced by Two Distinct Mechanisms of Antibody-Dependent Cellular Cytotoxicity against LFA-3 and HER2/Neu. Exp. Hematol. 1999, 27, 1533-1541. [CrossRef]

134. Sordo-Bahamonde, C.; Vitale, M.; Lorenzo-Herrero, S.; López-Soto, A.; Gonzalez, S. Mechanisms of Resistance to NK Cell Immunotherapy. Cancers 2020, 12, 893. [CrossRef]

135. Aldeghaither, D.S.; Zahavi, D.J.; Murray, J.C.; Fertig, E.J.; Graham, G.T.; Zhang, Y.-W.; O'Connell, A.; Ma, J.; Jablonski, S.A.; Weiner, L.M. A Mechanism of Resistance to Antibody-Targeted Immune Attack. Cancer Immunol. Res. 2019, 7, 230-243. [CrossRef] 
136. Corraliza-Gorjón, I.; Somovilla-Crespo, B.; Santamaria, S.; Garcia-Sanz, J.A.; Kremer, L. New Strategies Using Antibody Combinations to Increase Cancer Treatment Effectiveness. Front. Immunol. 2017, 8, 1804. [CrossRef] [PubMed]

137. Linares, J.; Rullan, A.; Taberna, M.; Vazquez, S.; Mesia, R. Emergence of Long-Term Surviving Patients with the Introduction of Cetuximab in Recurrent/Metastatic Disease of Squamous Cell Carcinoma of Head and Neck. Oral Oncol. 2016, 100, e4. [CrossRef] [PubMed]

138. Melero, I.; Berman, D.M.; Aznar, M.A.; Korman, A.J.; Gracia, J.L.P.; Haanen, J. Evolving Synergistic Combinations of Targeted Immunotherapies to Combat Cancer. Nat. Rev. Cancer 2015, 15, 457-472. [CrossRef] [PubMed]

139. Stagg, J.; Loi, S.; Divisekera, U.; Ngiow, S.F.; Duret, H.; Yagita, H.; Teng, M.W.; Smyth, M.J. Anti-ErbB-2 MAb Therapy Requires Type I and II Interferons and Synergizes with Anti-PD-1 or Anti-CD137 MAb Therapy. Proc. Natl. Acad. Sci. USA 2011, 108, 7142-7147. [CrossRef] [PubMed]

140. Griguolo, G.; Pascual, T.; Dieci, M.V.; Guarneri, V.; Prat, A. Interaction of Host Immunity with HER2-Targeted Treatment and Tumor Heterogeneity in HER2-Positive Breast Cancer. J. Immunother. Cancer 2019, 7, 90. [CrossRef] [PubMed]

141. Loi, S.; Giobbie-Hurder, A.; Gombos, A.; Bachelot, T.; Hui, R.; Curigliano, G.; Campone, M.; Biganzoli, L.; Bonnefoi, H.; Jerusalem, G.; et al. Pembrolizumab plus Trastuzumab in Trastuzumab-Resistant, Advanced, HER2-Positive Breast Cancer (PANACEA): A Single-Arm, Multicentre, Phase 1b-2 Trial. Lancet Oncol. 2019, 20, 371-382. [CrossRef]

142. Korman, A.; Chen, B.; Wang, C.; Wu, L.; Cardarelli, P.; Selby, M. Activity of Anti-PD-1 in Murine Tumor Models: Role of "Host" PD-L1 and Synergistic Effect of Anti-PD-1 and Anti-CTLA-4 (48.37). J. Immunol. 2007, 178 (Suppl. 1), S82.

143. Larkin, J.; Chiarion-Sileni, V.; Gonzalez, R.; Grob, J.J.; Cowey, C.L.; Lao, C.D.; Schadendorf, D.; Dummer, R.; Smylie, M.; Rutkowski, P.; et al. Combined Nivolumab and Ipilimumab or Monotherapy in Untreated Melanoma. N. Engl. J. Med. 2015, 373, 23-34. [CrossRef]

144. Siu, L.L.; Steeghs, N.; Meniawy, T.; Joerger, M.; Spratlin, J.L.; Rottey, S.; Nagrial, A.; Cooper, A.; Meier, R.; Guan, X.; et al. Preliminary Results of a Phase I/Ila Study of BMS-986156 (Glucocorticoid-Induced Tumor Necrosis Factor Receptor-Related Gene (GITR) Agonist), Alone and in Combination with Nivolumab in Pts with Advanced Solid Tumors. J. Clin. Oncol. 2017. [CrossRef] 